\title{
Anspruchskonkurrenz im internationalen Privatrecht
} Ein Beitrag zur Diskussion um die akzessorische Anknüpfung

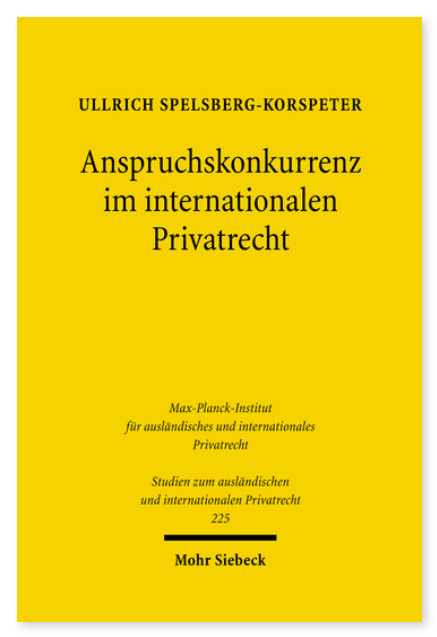

2009. XX, 171 Seiten. StudIPR 225

ISBN 978-3-16-151410-4

DOI 10.1628/978-3-16-151410-4

eBook PDF $64,00 €$

ISBN 978-3-16-150153-1

fadengeheftete Broschur 64,00€
Fast immer gibt es mehr als nur eine Anspruchsgrundlage, die von der Rechtsfolge her geeignet ist, das Begehren des Klägers zu stützen. Jede Rechtsordnung enthält daher - wenn auch meist ungeschriebene - Regeln, anhand derer zu entscheiden ist, ob mehrere Anspruchsgrundlagen nebeneinander anzuwenden sind oder ob eine von ihnen die übrigen ganz oder teilweise verdrängt. Treffen Anspruchsgrundlagen aus verschiedenen Rechtsordnungen zusammen, so kann es vorkommen, dass sich mehrere solcher Regeln widersprechen. Ullrich Spelsberg-Korspeter geht der Frage nach, wie mit der Gefahr derartiger Normenwidersprüche umzugehen ist. Ausgehend von einer Bestandaufnahme unter Einbeziehung der neu in Kraft getretenen Vorschriften der Rom II-Verordnung wird dabei insbesondere die im Schrifttum häufig befürwortete Methode der akzessorischen Anknüpfung kritisch gewürdigt.

Ullrich Spelsberg-Korspeter Geboren 1980; Studium der Rechtswissenschaft in Passau und Genf; 2009 Promotion; seit 2008 Richter auf Probe, Landgericht München I.
Jetzt bestellen:

https://mohrsiebeck.com/buch/anspruchskonkurrenz-im-internationalen-privatrecht-9783161514104?no_cache=1 order@mohrsiebeck.com

Telefon: $+49(0) 7071-923-17$

Telefax: $+49(0) 7071-51104$ 